(7) "First Book of Forestry," by Filibert Roth. This little elementary book is most charmingly written, giving in simple terms, and in an attractive form, the first principles of forestry. Although the illustrations are taken from species growing in the United States, I can strongly recommend the little book (published by Ginn and Company, pp. 26r, price $3 s .6 d_{\text {.) }}$ to landed proprietors and foresters in this country.

I have no doubt that these publications form only part of those which have lately appeared. All show signs of a good grasp of the subject, and prove the vigour with which it has been taken up. Asalready indicated, the forests of the United States are at present worked under a heavy deficit, as compared with production. This deficit will increase with the growth of the population and the further development of the industries of the country, and this will go on until a sufficient area of forests has been placed under systematic management. That measures to bring this about have not been taken a day too soon will be evident when it is considered what the requirements of the country are. Not only are enormous quantities of wood fuel wanted for a popula. tion of some 80 million peoples, but timber in proportion is required for pulp wood, posts, railway ties, poles for telegraphs and for piling, mining timber, ship timber, cooperage and wagon timber, lumber generally, and for many other purposes. To give an idea of what the total requirements may amount to, I shall pick out one or two items. There are upwards of 200,000 miles of railways in the States, which require annually some 70 million railway ties. To keep up this supply, some 8 to 10 million acres of well-managed forests are wanted. The annual requirements of general lumber are at present estimated at 30 billion feet, board measure, requiring not less than some 100 million acres of forests to keep up the supply. The demands for pulp wood and mining timber are already enormous, and likely to increase. The exports of timber from the States amount to a little more than one million tons a year, and these are already considerably exceeded by imports from Canada.

On the whole, then, the reservations made up to date can be considered only as a moderate beginning in the right direction. To meet the future requirements of the nation, the present area of reservations must be largely increased and they must all be brought under systematic protection and management. How. ever, the people and the Government are evidently determined to do what is necessary, and their efforts up to date bear testimony to the energy with which any question bearing on the general welfare of the nation is taken up and carried through.

Can we in this country not learn a lesson from the above facts, as we have been obliged to do in more than one other respect of late years? Our timber imports have latterly grown very rapidly, far more so than the increase of the population, while the sources of supply are becoming more and more precarious. It is all very well to say that we can pay for the imported timber, but what when the sources of supply fail? And all this time we have some 13 million acres of waste land and some 12 million acres of mountain and heath land used for light grazing in these islands, or a total of 25 million acres which yield a very small return or none at all. One. quarter of that area put under forest and treated in a rational manner would supply all the timber we require (apart from limited quantities of tropical timbers) and keep some 25 million pounds sterling in the country which we now send abroad every year to pay for the imported limber. And how many of the unfortunate unemployed, who are becoming the nightmare of our city authorities, would not find healthy employment in the country if a real effort were made to grow our own timber at home?

W. SCHLICH.

\section{THE ELECTROCHEMICAL SOCIETY.}

I AST March a few of those interested in the advancement of the study of electrochemistry in this country held a meeting in London. After some discussion as to the best means of advancing the object which it had in view, the meeting unanimously agreed to endeavour to form a society of electrochemists. A small committee was then appointed, which, after holding several meetings, sent out circulars to those who it was thought would be interested in the formation of such a society. A considerable number of favourable replies was received, but some who wrote deprecated the idea of adding yet another to the already large number of scientific societies. The committee then approached several existing societies, in order to see whether it might not be possible to work in conjunction with one or other of them. But although the replies received were couched in friendly terms, none of these societies seemed inclined to make any special effort to help forward the movement.

In these circumstances it was decided to call a general meeting of supporters of the movement to inaugurate an Electrochemical Society. By the kind permission of the committee of the Faraday Club, the meeting was held in the club rooms at the St. Ermin's Hotel, on the afternoon of February 4 .

Mr. Swinburne, chairman of the committee, took the chair, and briefly reviewed the circumstances which had brought the meeting together. He emphasised the importance of the electrochemical industry abroad, and pointed out how exceedingly backward we are in this country. $\mathrm{Mr}$. Swan, in a brief speech, then proposed the formation of the society, and said that there was no doubt but that it would be of great scientific and commercial value. $\mathrm{Mr}$. Alexander Siemens seconded the motion, which was carried unanimously.

Mr. Swinburne then read out a list of those who had been nominated by the committee and had expressed their willingness to serve on the council of the society. $\mathrm{Mr}$. Swan, F.R.S., was elected president, the vice-presidents being Lord Kelvin, Prof. Crum Brown, F.R.S., Sir Oliver Lodge, F.R.S., Lord Rayleigh, Mr. Ludwig Mond, F.R.S., $\mathrm{Mr}$. Alexander Siemens and Mr. J. Swinburne. The committee's recommendations were unanimously endorsed, and after a short discussion, and a vote of thanks to the committee of formation, the meeting separated.

The youngest of scientific societies in the country started off with a promised membership of 150 . There is, however, very little doubt but that in a short time many more, who have only been waiting for the movement to become an assured success, will join. Already since circulars calling the meeting were sent out, several who in the first place refused their support have sent in their names for membership.

The science of electrochemistry, which was initiated in this country through the splendid work of Davy and Faraday, has been allowed to languish, and but little attention has been paid to its great advancement abroad. In Germany a flourishing society, which issues a weekly journal, has been in existence for more than eight years. The Americans have a very vigorous society, which was established last year. The British society has been established with the object of advancing both pure and applied science. One is of ten met by the cry that electrochemical industry is all very well in countries where here is plenty of cheap waterpower, but that it will never be a success when you have to depend upon coal as an initial source of energy. But there is such a source of power as the Mond gas, and gas engines are every day becoming more perfect. Again, coal is cheaper in this country than in most places where there is an abundance of water-power. In some directions we may be handicapped; to a large extent this is due to our own inertness--our great chemist, Faraday, laid the foundationstone of electrochemical science--we have left it to others to build thereon. But the building is not complete; indeed, it may require to be partially pulled down and rebuilt. The Electrochemical Society has been formed to rehabilitate the science in this country, and its promoters look forward with the sanguine hope that when the scientific history of the next decade is written, British discoveries and inventions in the domain of electrochemistry will not be behind those of any other country.

All interested in electrochemistry and physical science and who are willing to help forward this society should send in their names to Mr. F. S. Spiers, Grosvenor Mansions, Victoria Street, Westminster.

\section{AGRICULTURAL NOTES.}

$\mathrm{I} \mathrm{N}$ a shilling pamphlet pablished at the offices of the Mark Lane Express, Mr. W. J. Malden, of the Colon al College, Hollesley Bay, discusses the m srits of ten new " poratoes with money in them." Hundreds of new varieties have been raised in the past few years; but nearly all of tho e named in the pamphlet have been produced by one grower--Mr. Findlay, of Markinch - and this fact indicates that to raise valuable new No. 1737 , vOL. 67$]$ 
kinds very special gifts are necessary. On the other hand, the developing of new sorts already on sale in limited quantities is much less difficult, and Mr. Malden shows that handsome profits may be made by those who are shrewd enough to recog. nise the coming varieties. Last year, for example, the kind known as "Northern Star" was selling at IOs. per lb. ; this season the price was $5 s$. per $\mathrm{lb}$., but it has now advanced to 15s. The tubers exhibited at the Smithfield show were priced at $7 s$. 6d. each! By growing plants from a single "eye" under garden conditions, the produce may be increased a hundredfold in one season. Thus Mr. Malden produced I68 plants and $4 \mathrm{I} 8 \mathrm{lb}$. of tubers from $4 \mathrm{lb}$. of "setts" planted in the spring of 1902. At the present time, there are a number of first-class kinds awaiting development, and it is to be hoped that Mr. Malden's remarks may induce a larger number of farmers and gardeners to give attention to the subject. From the public standpoint, it is much to be desired that good new sorts should be rapidly multiplied and brought into the vegetable market.

A simple demonstration conveying a useful lesson to the farmer has just been carried out at the new Harper-Adams Agricultural College, Shropshire. Seven cwt. of an ordinary compound manure (a "special turnip manure" sold at $6 l .15$ s. per ton) was applied to an acre of roots; to a second acre, the same quantity of plant food was given in the form of a mixture of superphosphate and sulphate of ammonia, followed by a top. dressing of nitrate of soda. The cost of the special manure was $47 s$. per acre, of the other $27 s .9 d$. The result, as was anticipated, was an almost equal yield of roots, and a saving by using the home-mixed manure of $\mathrm{I} l$. per acre. This demonstration wants repeating in every county, for there are two classes who have not yet learned to assess "special" manures at their real value-manure manufacturers and farmers.

Under the suggestive title of "A new Departure in the Science of Fattening," Mr. Warington contributes a valuable paper to the Agricultural Students' Gazelle (Cirencester). He discusses the recent work of Kellner on the feeding of farm animals, with special reference to the comparative effects of such fibrous fodders as hay and straw in the fattening of cattle. Agricultural chemists have held that the digestible nutrients in fodders of a similar character, such as oat and wheat straw, must have a similar value for the fattening animal, and they have argued that the comparative value must be shown by the composition. Practical agriculturists, on the other hand, hold that the chemical composition is not a correct index of the fodder's value, and they have never attached much weight to their scientific advisers' opinions of common farm fords.

The recent work of Zuntz (Berlin) and Kellner (Möckern) has shown that the farmer's opinion is correct and that a chemical analysis does not indicate the relative values of fodders grown under different conditions. The mechanical as well as the chemical composition has an important influence on the effects produced by a food on the fattening animal. A hard or tough straw requires more energy for its digestion than a softer one, this energy becomes a first charge upon the food, and thus the "efficiency" of an indigestible food is lower than that of a digestible one of the same chemical composition. It has, of course, been known that digestion involves an expenditure of energy, but Zuntz and Kellner have been the first to show how great the effect of this may be on the value of a fodder.

The former worker so long ago as 1896 wrote a paper for the American Experiment Station Record in which he discussed this question, pointing out that in the case of the horse the nutrients assimilated from hay yielded 20 per cent. less available energy than the same nutrients assimilated from grain; but the importance of Zuntz's work does not seem to have been appreciated in this country. Kellner's experiments are, how. ever, likely to arouse widespread interest. He has compared the effects produced on fattening oxen by nutrients derived from various sources, and among other results he finds that to produce the same increase as is due to $100 \mathrm{lb}$. of starch it is necessary to supply $147 \mathrm{lb}$. digestible nutrients in meadow hay, $157 \mathrm{lb}$. in oat straw, and no less than $374 \mathrm{lb}$. in wheat straw. The figures, of course, hold good only for the particular samples of hay and straw used by Kellner; the importance of the result lies in the fact that a wide variation in value has been proved. Kellner's experiments may nut, perhaps, affect the rations given by the farmer to his cattle, but they will very greatly affect the rations which he (the farmer) has hitherto been recommended to use.

No. 1737 , voL. 67]
The December number of the United States Experiment Station Record contains a short report of the sixteenth annual convention of the Association of American Agricultural Colleges and Experiment Stations. Among the papers read was one which emphasised the importance of breeding and selecting corn for different purposes, showing how much the market value might be affected by slight variations in the composition. The composition of the grain of cereals is a subject to which our English seed growers have hitherto given little attention. Wheat, for example, has been selected for appearance, for yield and for stiffness of straw, but the chemical composition has been neglected, with the result that the miller and baker condemn our present English wheats as inferior and unsuit. able for flour-making. We grow about one-fourth only of what we consume, but so small is the proportion of homegrown wheat which millers can profitably mix with imported grain that the markets are often glutted with English wheat which millers will not buy. A very slight alteration in the chemical composition would enable millers to employ profitably 35 per cent. to 40 per cent. of English wheat in their mixtures, instead of 25 per cent. to 30 per cent, as at present, and would thus remove the possibility of glutting the market with English wheat. In ten or fifteen years time, we may hope to see this change in composition effected. In the meantime, it would be interesting to follow the lead of the American writer, trace the effect of composition on market value, and investigate the loss the nation has suffered in the past decade or two and must continue to suffer for years to come from this oversight on the part of our seed growers.

T. H. M.

\section{WEST INDIAN NOTES.}

THE third number of vol. iii. of the West Indian Bulletin, issued by the Imperial Agricultural Department, contains a large amount of information on a variety of subjects. Mr. Francis Watts deals with "Raw Sugars for Brewing Purposes," Mr. P. C. Cork with "Stock Rearing in Jamaica," Mr. Maxwell-Lefroy with "Scale Insects of the West Indies," \&c. A lengthy account, 23 pages, of the volcanic eruptions in the West Indies includes a reproduction in full of a most interesting series of observations taken by the Rev. N. B Watson, at his residence, about twelve miles east of Bridgetown, Barbados, from 5 a.m., October I4, to 6 a. m., October I 7, covering the period of the Soufrière eruption in St. Vincent on October $15^{-16}$ and the dust fall in Barbados. Careful notes were taken of the direction and force of the wind, temperature, clouds, aspect of the sun, sky, the atmosphere, \&c., and the rate at which the dust fell was frequently measured, the heaviest being 38.1 grammes per square foot, from noon to $1 \mathrm{p} \mathrm{m}$. on October 16.

The Department has also just published Nos. 19 and 20 of its pamphlet series, dealing with seedling and other canes at Barbados and in the Leeward Islands respectively. Of the large number of varieties of seedlings experimented with, the results for the past season show B. 208 to be the best allround cane, beating all its rivals in Barbados, Antigua, St. Kitts and Trinidad. In Barbados, its juice was described as "exceedingly rich and pure," in Antigua as "exceptionally rich in sugar," and in St. Kitts as "of remarkable richness and purity." Part $i$. of the report on the sugar-cane experi. ments conducted at Antigua and St. Kitts in the season I90I-02, published at the same time, contains the complete statistical results for the two islands.

The report on the Antigua Botanic Station for the year ending March 3I last contains full particulars of the working of a "Peasant's Garden," in which nothing is done that cannot easily be accomplished by a working man having a similar small piece of land. In the previous year, the experimental plot was one-tenth of an acre; it required an expenditure, for labour, seeds and manure, of $1 l .15 s_{3} 3 d$, and the varied produce, when sold, fetched $2 l$. I5s., leaving a profit at the rate of nearly Iol. per acre. Last year the area was increased to one-seventh of an acre; the expenditure was $3 l$. IIs., and the produce realised $4 l$. I6s. II $d$., showing a profit of about 9l. per acre. In re-afforestation experiments, about a dozen varieties of trees were being tested, the best growing being found to be mahogany and white cedar. It is curious that, while in neighbouring islands sugar-cane seedlings have been successfully raised, the several attempts made in Antigua have almost invariably turned out failures, very few fertile 